\title{
Seasonal variability of stable isotopes in the Changjiang (Yangtze) river water and its implications: natural climate and anthropogenic impacts
}

Chao Li ( $\nabla$ cli@tongji.edu.cn )

Tongji University https://orcid.org/0000-0001-8571-6531

Ergang Lian

Tongji University

Chengfan Yang

Tongji University

Kai Deng

Tongji University

Peng Qian

Nantong University

Shangbin Xiao

China Three Gorges University

Zhongfang Liu

Tongji University

Shouye Yang

Tongji University

\section{Research}

Keywords: Stable hydrogen and oxygen isotopes, water cycle, Changjiang (Yangtze) River, precipitation, damming effect

Posted Date: December 13th, 2019

DOI: https://doi.org/10.21203/rs.2.18549/v1

License: (1) This work is licensed under a Creative Commons Attribution 4.0 International License.

Read Full License 
Version of Record: A version of this preprint was published at Environmental Sciences Europe on May 29th, 2020. See the published version at https://doi.org/10.1186/s12302-020-00359-w. 


\section{Abstract}

\section{Background}

Seasonal variations of stable hydrogen and oxygen isotopes in river water can be used to indicate hydrological processes and the water cycle in the river basin. This study presents a high-resolution time series of stable oxygen isotopic record ( $\delta 180$ ) in the lower Changjiang (Yangtze) River mainstream and aims to investigate the regional water cycle concerning natural climate changes and anthropogenic activities.

Results

The river water $\delta 180$ shows apparent seasonal variations, which in overall higher during the dry season and lower during the flood season. This basin-scale seasonal variation of $\delta 180$ in precipitation over the Changjiang catchment is calculated based on the long-term meteorological and hydrological data. The seasonal variation of $\delta 180$ in the lower Changjiang river water is largely constrained by monsooninduced precipitation, but are more directly controlled by the mixing of waters from the upper reaches and the tributary lakes in the middle valley.

\section{Conclusions}

The relative contributions of waters from the upstream and tributary lakes to the lower Changjiang mainstream have been considerably altered by the construction of Three Gorges Dam via the regulation of river discharges. A comparison of river water isotopic records with water discharges from the lakes suggests that it takes about two weeks ( 17 days) for the Changjiang river water to circumvent the midlower reaches of the catchment before traveling to the sea. This study suggests that the stable hydrogen and oxygen isotopes can be harnessed as sensitive indicators for water cycling within a large catchment that is driven primarily by natural forcing though subject to substantial human impacts.

\section{Background}

Over the past three decades, stable hydrogen $(\mathrm{H})$ and oxygen $(0)$ isotopic compositions in river water have provided deep insights into various hydrological processes and river water cycling at different spatial and temporal scales [1-6]. In general, these studies were mostly conducted in small and wellinstrumented catchments with drainage areas ranged from 0.01 to $100 \mathrm{~km}^{2}$ and located typically in headwater regions, yet little attention is paid to the larger (100 to $>1000 \mathrm{~km}^{2}$ in catchment area), and the poorer-instrumented basins [2, 7]. Isotopic responses are often intricate in large river systems, which often reflect an integrated influence of hydrological processes from meteoric precipitation to various discharges, including those from the groundwater, melting glaciers, dams, lakes, karst terrain, evaporation, snowmelt events, and tributary mixing $[8,9]$. The use of isotopic tracer has been greatly limited in the river due to the lack of long-term isotopic data [10]. For instance, though a conceptual framework has been established in estimating global isotope balance, the isotope mass balance on 
modern continents has remained poorly understood, primarily due to the lack of long-term systematic observations on riverine fluxes to the oceans [4]. Moreover, the reconstructions of continental palaeoclimate and palaeohydrology based on stable isotopic signals preserved in various archives may be hampered by poor recognition of the modern isotopic patterns and the hydrologic cycle. Therefore, it is crucial to commence with a long-term stable isotope monitoring for the collection of baseline isotopic data. Moreover, the long-term stable isotopic observations in the extensive river system can improve our understanding on the sustainable management of water supply, flood-drought cycles, ecosystem, and human health in the catchments [2].

In the year 2002, the International Atomic Energy Agency (IAEA) launched a coordinated research project entitled "Isotope tracing of hydrological processes in large river basins," aimed to develop and examine quantitative isotopic analysis methods for water balance and related hydrological processes. In 2007, another research program, "Global Network of Isotopes in Rivers (GNIR)," also led by IAEA, compiled isotopes data from global rivers to complement with the IAEA/World Meteorological Organization (WMO)'s database of the "global network of isotopes in precipitation" (GNIP). The GNIR encourages systematic collections of global river water isotopic data to provide a better understanding of the resilience of major global river systems to environmental and human perturbations.

The Changjiang (Yangtze) River is the longest (about 6,397 km) river in Asia and the third-longest in the world, and it plays a vital role in the socio-economic development of China. Over the past five decades, water consumption has increased dramatically due to the domestic, industrial, and agricultural developments in the Changjiang catchment. Anthropogenic perturbation mainly constituted of deforestation, dam/reservoirs construction, and sand/stone excavation. Today, the Changjiang River subjectes to increasing environmental problems such as floods and droughts, e.g., 1320 people died in the disastrous floods in 1998 with a direct economic loss exceeding 166 billion CNY [11]. Furthermore, water quality and its ecosystem [12,13], water and soil loss [14], erosion of river channel, and delta [1519] within the Changjiang catchment are all of the prodigious concerns to the government, public, as well as the scientists.

A systematic investigation of $\mathrm{H}$ and $\mathrm{O}$ isotopes in the Changjiang river water was initiated in 2002 by a program namely "The isotopic tracing of hydrology processes in the Yangtze River basin", which was a joint-research with "Designing criteria for a network to monitor isotope composition of runoff in large rivers" by IAEA [20]. This investigation provides the first systematic analysis of stable $\mathrm{H}$ and $\mathrm{O}$ isotopes in the Changjiang River, which then inspired a series of investigations focused on spatial and temporal variations of stable isotopes [21-28]. These studies suggest that the $\delta D$ and $\delta^{18} O$ of the Changjiang river water increase gradually from the upstream to estuary due to reducing runoff influences from the alpine catchments [23],"continental effect” [29] of the local precipitation [20]凶and increasing water contributions from tributary rivers and lakes in the middle and lower reaches [23, 30, 31]. Notwithstanding, these studies mainly focus on the spatial distribution of $\mathrm{H}$ and $\mathrm{O}$ isotopes along the Changjiang River, while few explicit analyses concerning the seasonal isotopic variations were conducted [32]. 
In this study, we present a high-resolution $\mathrm{H}$ and $\mathrm{O}$ isotopes time series in the lower Changjiang mainstream to develop an application of isotopic tracers for surface water cycle in a large river basin subject to the sophisticated natural setting and is facing increasing human activities. The primary purpose of this study is to: 1 ) identify the seasonal variations of $\mathrm{H}$ and $\mathrm{O}$ isotopes in the Changjiang river water and its associated controlling mechanisms; 2) to elucidate how natural climate change and human activities affect the water cycle in the Changjiang River.

\section{Methods}

A total of 75 river water samples were collected from the lower Changjiang mainstream close to Nantong $\left(31.96^{\circ} \mathrm{N}, 120.83^{\circ} \mathrm{E}\right.$; Fig. 1) from November 12,2012 , to December 13,2014 , with the sampling interval ranged from one to two weeks. 6 other supplementary water samples were taken from Dongting Lake (4 samples) and Poyang Lake (2 samples) between 2012 and 2013 (Supplementary Table 1). The lake water were collected close to the confluence where lake water first met the Changjiang mainstream. All of the water samples were collected at the depth of about $50 \mathrm{~cm}$ below the water surface and sealed in the plastic bottles immediately after collection. The samples were analyzed for stable hydrogen and oxygen isotopes using the Isotopic Water Analyzer (IWA-45EP, Los Gatos Research, USA) in the State Key Laboratory of Marine Geology at Tongji University, Shanghai. The results are presented in relative abundance ( $\delta \mathrm{D}$ and $\delta^{18} \mathrm{O}$, respectively) of $\mathrm{D}$ and ${ }^{18} \mathrm{O}$ isotopes, given in per mil (\%o) with reference to the international standard VSMOW (Vienna Standard Mean Ocean Water). The precisions of $\delta \mathrm{D}$ and $\delta^{18} \mathrm{O}$ measurements are higher than $\pm 0.5 \%$ ond $\pm 0.1 \%$, respectively.

Existing $\delta D$ and $\delta^{18} O$ data available in the river water from Chongqing, Datong, and in the lake water from Dongting and Poyang are used as references in the study. This study referred to the $\delta^{18} \mathrm{O}$ values of the monthly precipitation in the selective sites over the Changjiang catchment (Fig. 2), and the precipitation data derived mainly from the GNIP (IAEA) isotopic database. Detailed information on the samples and reference data can be found in Table 1 and Supplementary Table 1. 
Table 1

Average $\delta^{18} \mathrm{O}$ (standard deviations in brackets) in precipitation for each Changjiang sub-basin.

\begin{tabular}{|c|c|c|c|c|c|c|c|c|c|c|}
\hline Month & $\mathrm{LS}^{\mathrm{a}}$ & KM & $C D$ & $\mathrm{CQ}$ & ZY & CS & WH & YT & NJ & $\mathrm{CU}$ \\
\hline & $\left(A_{1}\right)^{b}$ & $\left(A_{2}\right)$ & (B) & $(C, D)$ & $(E)$ & $(\mathrm{H})$ & $(G, F)$ & (I) & (J) & (K) \\
\hline Jan. & -10.45 & $\begin{array}{l}-3.01 \\
( \pm \\
1.50)\end{array}$ & $-^{c}$ & - & $\begin{array}{l}-3.72 \\
( \pm \\
2.19)\end{array}$ & $\begin{array}{l}-5.34 \\
( \pm \\
2.40)\end{array}$ & $\begin{array}{l}-5.91 \\
( \pm \\
1.95)\end{array}$ & -4.26 & $\begin{array}{l}-7.89 \\
( \pm \\
0.76)\end{array}$ & -5.04 \\
\hline Feb. & - & $\begin{array}{l}-5.42 \\
( \pm \\
2.39)\end{array}$ & $\begin{array}{l}-3.13 \\
( \pm \\
1.64)\end{array}$ & - & $\begin{array}{l}-2.36 \\
( \pm \\
1.28)\end{array}$ & $\begin{array}{l}-4.35 \\
( \pm \\
0.55)\end{array}$ & $\begin{array}{l}-4.33 \\
( \pm \\
2.03)\end{array}$ & -4.76 & $\begin{array}{l}-5.97 \\
( \pm \\
0.54)\end{array}$ & -5.76 \\
\hline Mar. & $\begin{array}{l}-16.83 \\
( \pm \\
5.25)\end{array}$ & $\begin{array}{l}-8.17 \\
( \pm \\
3.18)\end{array}$ & $\begin{array}{l}-1.34 \\
( \pm \\
5.01)\end{array}$ & - & $\begin{array}{l}-3.25 \\
( \pm \\
1.22)\end{array}$ & $\begin{array}{l}-3.33 \\
( \pm \\
0.36)\end{array}$ & $\begin{array}{l}-5.19 \\
( \pm \\
2.41)\end{array}$ & -4.00 & $\begin{array}{l}-6.75 \\
( \pm \\
3.12)\end{array}$ & -3.01 \\
\hline Apr. & $\begin{array}{l}-8.38 \\
( \pm \\
3.77)\end{array}$ & $\begin{array}{l}-12.37 \\
( \pm \\
2.22)\end{array}$ & $\begin{array}{l}-2.14 \\
\pm \\
1.88)\end{array}$ & - & $\begin{array}{l}-4.08 \\
( \pm \\
3.85)\end{array}$ & $\begin{array}{l}-2.22 \\
( \pm \\
1.54)\end{array}$ & $\begin{array}{l}-2.16 \\
( \pm \\
1.86)\end{array}$ & -3.50 & $\begin{array}{l}-2.91 \\
\pm \\
1.61)\end{array}$ & -4.55 \\
\hline May & $\begin{array}{l}-6.51 \\
( \pm \\
7.80)\end{array}$ & $\begin{array}{l}-13.10 \\
( \pm \\
2.62)\end{array}$ & $\begin{array}{l}-2.02 \\
( \pm \\
1.22)\end{array}$ & - & $\begin{array}{l}-4.67 \\
( \pm \\
2.39)\end{array}$ & $\begin{array}{l}-3.04 \\
( \pm \\
2.94)\end{array}$ & $\begin{array}{l}-3.01 \\
( \pm \\
1.38)\end{array}$ & -4.38 & $\begin{array}{l}-4.49 \\
( \pm \\
1.59)\end{array}$ & -5.84 \\
\hline Jun & $\begin{array}{l}-9.19 \\
( \pm \\
5.08)\end{array}$ & $\begin{array}{l}-10.75 \\
( \pm \\
1.69)\end{array}$ & $\begin{array}{l}-5.08 \\
( \pm \\
1.73)\end{array}$ & -9.16 & $\begin{array}{l}-7.91 \\
( \pm \\
2.32)\end{array}$ & $\begin{array}{l}-7.53 \\
( \pm \\
1.54)\end{array}$ & $\begin{array}{l}-7.14 \\
( \pm \\
2.76)\end{array}$ & -6.67 & $\begin{array}{l}-9.55 \\
( \pm \\
1.20)\end{array}$ & -8.89 \\
\hline Jul. & $\begin{array}{l}-13.96 \\
( \pm \\
4.48)\end{array}$ & $\begin{array}{l}-10.49 \\
( \pm \\
2.70)\end{array}$ & $\begin{array}{l}-7.75 \\
( \pm \\
1.00)\end{array}$ & -11.06 & $\begin{array}{l}-10.99 \\
( \pm \\
2.92)\end{array}$ & $\begin{array}{l}-9.11 \\
( \pm \\
1.53)\end{array}$ & $\begin{array}{l}-9.63 \\
( \pm \\
0.38)\end{array}$ & -10.85 & $\begin{array}{l}-9.88 \\
( \pm \\
1.28)\end{array}$ & -8.71 \\
\hline Aug. & $\begin{array}{l}-21.55 \\
( \pm \\
3.22)\end{array}$ & $\begin{array}{l}-8.58 \\
( \pm \\
2.74)\end{array}$ & $\begin{array}{l}-9.46 \\
( \pm \\
2.05)\end{array}$ & -11.93 & $\begin{array}{l}-10.20 \\
( \pm \\
3.02)\end{array}$ & $\begin{array}{l}-7.67 \\
( \pm \\
2.97)\end{array}$ & $\begin{array}{l}-7.35 \\
( \pm \\
1.30)\end{array}$ & -8.70 & $\begin{array}{l}-9.13 \\
( \pm \\
1.21)\end{array}$ & -7.51 \\
\hline Sep. & $\begin{array}{l}-15.87 \\
( \pm \\
4.73)\end{array}$ & $\begin{array}{l}-5.15 \\
( \pm \\
2.06)\end{array}$ & $\begin{array}{l}-7.33 \\
( \pm \\
1.77)\end{array}$ & -12.82 & $\begin{array}{l}-10.92 \\
( \pm \\
2.74)\end{array}$ & $\begin{array}{l}-9.74 \\
( \pm \\
2.78)\end{array}$ & $\begin{array}{l}-7.30 \\
( \pm \\
3.51)\end{array}$ & -8.95 & $\begin{array}{l}-7.99 \\
( \pm \\
1.18)\end{array}$ & -7.78 \\
\hline Oct. & $\begin{array}{l}-22.37 \\
( \pm \\
4.40)\end{array}$ & $\begin{array}{l}-4.32 \\
( \pm \\
3.22)\end{array}$ & -9.08 & -11.89 & $\begin{array}{l}-8.53 \\
( \pm \\
3.06)\end{array}$ & $\begin{array}{l}-6.02 \\
( \pm \\
2.35)\end{array}$ & $\begin{array}{l}-6.86 \\
( \pm \\
2.55)\end{array}$ & -6.41 & $\begin{array}{l}-6.66 \\
( \pm \\
1.91)\end{array}$ & -5.31 \\
\hline
\end{tabular}

${ }^{a}$ Abbreviations for isotopic observation stations in the Changjiang catchment. $\mathrm{LS}=\mathrm{Lhasa} ; \mathrm{KM}=$ Kunming, $C D=$ Chengdu, $C Q=$ Chongqing, $Z Y=$ Zunyi, $C S=$ Changsha, $W H=$ Wuhan, $N J=$ Nanjing; $Y T$ = Yingtan; $\mathrm{CU}=$ Changshu. Data for YT and CU station is referred from Liu et al. [42], while the rest is from GNIP (http://www-naweb.iaea.org/napc/ih/IHS_resources_isohis.html)

${ }^{\mathrm{b}}$ The 12 sub-basins of the Changjiang catchment are indicated by capital letters from $A_{1}$ to $\mathrm{K}$ in Fig. 5 .

${ }^{\mathrm{c}}$ No data available. 


\begin{tabular}{|c|c|c|c|c|c|c|c|c|c|c|}
\hline Month & $\mathrm{LS}^{\mathrm{a}}$ & KM & $C D$ & CQ & $Z Y$ & CS & WH & YT & NJ & CU \\
\hline Nov. & -11.05 & $\begin{array}{l}-3.15 \\
( \pm \\
3.02)\end{array}$ & $\begin{array}{l}-4.52 \\
( \pm \\
2.28)\end{array}$ & - & $\begin{array}{l}-6.97 \\
( \pm \\
2.48)\end{array}$ & $\begin{array}{l}-4.68 \\
( \pm \\
1.99)\end{array}$ & $\begin{array}{l}-7.24 \\
( \pm \\
1.32)\end{array}$ & -6.92 & $\begin{array}{l}-7.18 \\
( \pm \\
3.17)\end{array}$ & -6.25 \\
\hline Dec. & -14.52 & $\begin{array}{l}-3.51 \\
( \pm \\
2.76)\end{array}$ & -7.20 & - & $\begin{array}{l}-3.85 \\
( \pm \\
1.12)\end{array}$ & $\begin{array}{l}-4.12 \\
( \pm \\
2.68)\end{array}$ & $\begin{array}{l}-5.07 \\
( \pm \\
0.78)\end{array}$ & -4.38 & $\begin{array}{l}-8.06 \\
( \pm \\
1.81)\end{array}$ & -5.87 \\
\hline \multicolumn{11}{|c|}{ 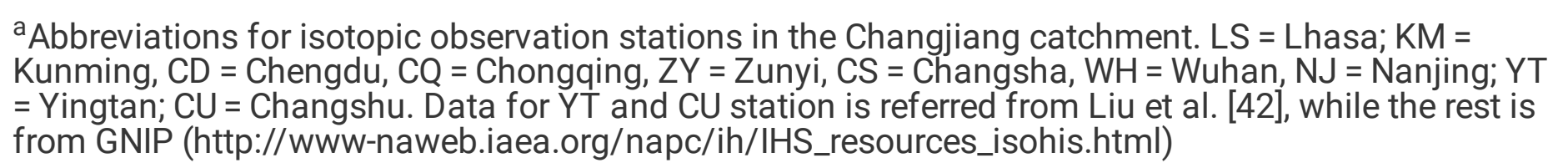 } \\
\hline \multicolumn{11}{|c|}{${ }^{\mathrm{b}}$ The 12 sub-basins of the Changjiang catchment are indicated by capital letters from $\mathrm{A}_{1}$ to $\mathrm{K}$ in Fig. 5 . } \\
\hline${ }^{c}$ No da &. & & & & & & & & & \\
\hline
\end{tabular}

\section{Results}

\section{Seasonal variations of river water $\delta D$ and $\delta^{18} 0$ in the Changjiang mainstream}

The $\delta D$ and $\delta^{18} \mathrm{O}$ isotopic ratios in the Changjiang river water in Nantong are given in Supplementary Table 1. The $\delta \mathrm{D}$ ranges from $-73.3 \%$ o to $-38.3 \%$, with a mean value of $-56.4 \%$, while $\delta^{18} \mathrm{O}$ varies from $-10.6 \%$ o to $-6.4 \%$ o with an average of $-8.5 \%$. A plot of $\delta D$ versus $\delta^{18} \mathrm{O}$ (Fig. 3 ) reveals that the Changjiang river samples (excluding the lake samples) show a strong positive linear relationship: $\delta D=$ $8.5 \times \delta^{18} O+15.5\left(R^{2}=0.98\right)$. Both $\delta D$ and $\delta^{18} O$ in the lower Changjiang mainstream in Nantong and Datong are higher than those in the upper mainstream in Chongqing. As $\delta D$ is highly correlated with $\delta^{18} O$ in the Changjiang river water, only $\delta^{18} \mathrm{O}$ will be discussed in the following discussion.

The $\delta^{18} 0$ time series data in the Changjiang river water is presented in Fig. 4a, showing an evident seasonal variation between dry and flood seasons. During our sampling period, the $\delta^{18} \mathrm{O}$ is in overall enriched in the dry season (November to April) but depleted during the flood season (May to October). The seasonal $\delta^{18} \mathrm{O}$ variability in Nantong is very similar to that of Datong (Fig. $4 a$ ), which is as well located in the lower Changjiang reaches but upstream of Nantong. The seasonal variation of $\delta^{18} \mathrm{O}$ in Poyang Lake is always higher but relatively stable than that of Nantong within the year, while the seasonal $\delta^{18} \mathrm{O}$ variability in Chongqing, which is located in the upper Changjiang reaches, is much variable and in overall lower except in May and June. The $\delta^{18} \mathrm{O}$ in Nantong and Datong fell within the ranges between Chongqing and the Poyang Lake. Note that some discrete data (scattered points in Fig. 4a) from the Dongting Lake, Poyang Lake, and Chongqing station (this study and reference data) are also compared to assess for the representative time-series samples. 


\section{Basin-scale seasonal precipitation $\delta{ }^{18} 0$ in Changjiang River basin}

The topography in the Changjiang River catchment is sewn by three China continent terraces, spanned from the western highlands to the eastern low-relief delta plain. The river basin subjects to two different monsoon climate regimes, the East Asian Monsoon system in the middle/lower valleys and the Indian Monsoon zone in the uppermost basin and source area [33]. As a result, the precipitation amount and its $\delta^{18} \mathrm{O}$ value varies in space and times within the Changjiang catchment.

In this regarding, a basin-scale seasonal variation in precipitation $\delta^{18} \mathrm{O}$ is a prerequisite for a comprehensive $\delta^{18} \mathrm{O}$ comparison between the precipitation and river water. To evaluate for the total precipitation in Changjiang catchment, the catchment is divided into 12 sub-basins based on unique characteristics possessed by its tributaries, alphabetically named from Zone $A_{1}$ to Zone $K$ from the upper river basin to the river mouth (Fig. 5). A total of 12 GNIP stations with multi-year records of precipitation $\delta^{18} \mathrm{O}$ were selected to quantify the precipitation of each sub-basin. Meanwhile, long-term precipitation data and sub-basin coverage areas are used to calculate the precipitation amount for each sub-basin. On this basis, the sub-basin weighted $\delta^{18} \mathrm{O}$ in precipitation covering the Changjiang river basin in each month can be estimated by the following Eq. (1),

$$
\delta^{18} O=\frac{\sum\left(\delta^{18} O_{i} \times P_{i} \times A_{i}\right)}{\sum\left(P_{i} \times A_{i}\right)}
$$

where $\delta^{18} \mathrm{O}_{\mathrm{i}}$ stands for monthly $\delta^{18} \mathrm{O}$ in station $\mathrm{i}, \mathrm{P}_{\mathrm{i}}$, and $\mathrm{A}_{\mathrm{i}}$ represent the precipitation amount and area for the corresponding sub-basin. The details of each station and sub-basin are listed in Tables 1 and 2.

The monthly sub-basin weighted precipitation $\delta^{18} \mathrm{O}$ data are displayed in Fig. 4a. The precipitation $\delta^{18} \mathrm{O}$ in the Changjiang catchment is overall higher $(\sim-4 \%$ ) from January to May, albeit with a decreasing trend, and remains lower from June to October $(\sim-10 \%)$, finally increases to a high level again in November and December. In other words, the precipitation $\delta^{18} \mathrm{O}$ is higher in the dry season (winter) but lower in flood season (summer). The precipitation $\delta^{18} \mathrm{O}$ has a similar overall trend with the river water $\delta^{18} \mathrm{O}$ in the time-series monitoring, albeit with considerable variability.

\section{Discussions}

\section{Changjiang River geological setting}

The Changjiang River originates from the Tibetan Plateau $(\sim 5,170 \mathrm{~m}$ in altitude on average) and enters the East China Sea near the city of Shanghai, with a watershed of about $1.8 \times 10^{6} \mathrm{~km}^{2}$ (Fig. 1). 
Changjiang tributary is extensively developed in its large drainage basin, which fosters 49 tributaries with each catchment area covers over $10,000 \mathrm{~km}^{2}$. Traditionally, the upper reaches of the Changjiang River refers to the section from Yibin to Yichang; the middle refers to the section from Yichang to Hukou, where Poyang Lake meets the river; whereas the lower reaches extended from Hukou to the river mouth. The Jinshajiang River, as the largest tributary of the Changjiang river system, joins the mainstream in Yibin, where the "Changjiang" formally named. Many of the large tributaries of the Changjiang River are located in the upstream of the Three Gorges. The two most significant freshwater lakes, Poyang Lake and Dongting Lake, are located in the middle, and lower Changjiang reaches, with basin coverage up to $4,125 \mathrm{~km}^{2}$ and $4,040 \mathrm{~km}^{2}$, respectively. Both lakes receive river water from several tributaries as well as the Changjiang mainstream (Fig. 1), which exerts an essential role in buffering the flood from the Changjiang upstream during the flood season.

The Changjiang River basin is located primarily in the subtropical and temperate climate zone, and most parts of the basin prevailed by the subtropical monsoon climate. Two types of monsoon current flow through the basin in a year, the Siberian northwest winter monsoon and the Asian southeast summer monsoon (or Indian southwest summer monsoon in the upper Changjiang reaches) [33]. Changjiang River discharge sourced primarily from precipitation. The mean annual precipitation was $1,057 \mathrm{~mm}$, made up of an approximate total discharge of $1,912 \times 10^{9} \mathrm{~m}^{3} /$ year. In general, the summer monsoon initiated in April and impacts the Changjiang basin then retreats in October, which determines the timing of the rainy season from May to October, and most precipitation concentrates from July to August [34]. However, the spatial and temporal variations of precipitation in the Changjiang catchment are rather intricate and highly associated with the prevailing monsoon system and diverse topography. As a whole, about $70 \sim 90 \%$ of the total annual precipitation occurred from May to September, with significant temporal variations but no apparent long-term trend observed over the last five decades (Fig. 2a). On the other hand, the spatial distribution of rainfall is particularly irregular [35]. Overall, the rainfall in general decreases from the southeast (lower reaches) to the northwest (upper reaches) of the basin because of the migration of monsoon-induced rain front from the southeast to the northwest of the coastal region in China [34].

\section{Distribution of $\delta D$ and $\delta{ }^{18} 0$ in the Changjiang river water}

The water on the land surface is predominantly replenished by precipitation during the global water cycle. As a result, $\delta D$ and $\delta^{18} O$ in the river water are determined by the isotopic composition of precipitation and thus may serve as a good proxy for precipitation isotopic composition [1]. However, in some cases, the $\delta D$ and $\delta^{18} \mathrm{O}$ in river water are different from the local precipitation due to evaporation, transpiration from different altitudes [4]. In particular, for the large rivers, the $\delta D$ and $\delta^{18} O$ of river water may vary significantly from the precipitation as a result of the "catchment effect" [36]. In Fig. 3, the regression line of $\delta D$ and $\delta^{18} O$ for the Changjiang river water is $\delta D=8.5 \times \delta^{18} O+15.5\left(R^{2}=0.98\right)$, displays a more pronounced slope and higher intercept than GMWL [37]. However, the correlation of river water $\delta \mathrm{D}$ and 
$\delta^{18} \mathrm{O}$ in accordance with local meteoric water line (LMWL) observed in specific cities in the Changjiang catchment, e.g. $\delta D=7.34 \times \delta^{18} O+2.56 \%$ o ( $R^{2}=0.98$; Kunming site), $\delta D=8.47 \times \delta^{18} 0+15.46 \%$ o $\left(R^{2}=0.99\right.$; Changsha site) and $\delta D=8.43 \times \delta^{18} 0+17.46 \%$ o $\left(R^{2}=0.98\right.$; Nanjing site $)$, which are calculated based on archived precipitation data retrieved from GNIP [38].

Compared to the riverine samples, the lake samples show the highest $\delta D$ and $\delta^{18} O$ values and significant variations, which suggest that the lake water in the Changjiang catchment suffers from more significant evaporative fractionation than river water. The river water samples from Chongqing in the upstream are more depleted in both $\delta D$ and $\delta^{18} 0$ than those from the lakes in the middle reaches and from Nantong and Datong downstream. $\delta^{18} \mathrm{O}$ depletion in the Changjiang river water with increasing elevation is probably due to the "continent effect/elevation effect," which has been thoroughly investigated by [20] and [23].

These substantial differences in isotopic ratios between Changjiang sub-basins are primarily fashioned by different isotopic compositions in the local precipitation, and partly by the combined effects of evaporation, groundwater replenishment, and perhaps snow melting in the mountain area in each specific sub-basin $[20,23,30]$.

\section{Seasonal variation of $\delta{ }^{18} 0$ for the precipitation in a basin- scale}

A deep insight into the spatial distribution of precipitation isotopes will improve our understanding of large-scale catchment water cycling dynamics. In the 1980s and 1990s, GNIP has been systematically monitored over the precipitation $\delta D$ and $\delta^{18} \mathrm{O}$ in the Changjiang catchment. Among the 37 GNIP stations in China, 8 stations were set up within the Changjiang catchment to collect the primary isotopic data of precipitation across the basin. In most of the mid- and high-latitude land areas, the precipitation $\delta^{18} \mathrm{O}$ is enriched in summer and depleted in winter due to the nature of the $\delta \mathrm{D}$ and $\delta^{18} \mathrm{O}$, which are positively correlated with temperature [39]. However, this seasonal isotopic trend was reversed in the coastal region of East China, e.g., the Changjiang catchment (Fig. 4a), where $\delta D$ and $\delta^{18} O$ values are higher in winter than in the summer $[33,40]$. During the past decades, many investigators have attempted to explain the isotopic characteristics of precipitation observed in East China, and most agree that the isotopic characteristics of precipitation are strongly regulated by the distinct monsoon system and topography in East Asia [33, 40-47].

However, previous studies on precipitation isotopes in the Changjiang catchment were based primarily on the data from the individual meteorological station, while the basin-scale isotopic characteristics have scarcely investigated. As the spatial distribution of the rainfall is exceptionally irregular in the Changjiang basin, the rainfall amount and its $\mathrm{H}$ and $\mathrm{O}$ isotopic composition can vary by region, especially between the upper and lower reaches [33, 40,42]. The Changjiang river water, in particular from the lower reaches, 
integrates the water from the entire basin. Therefore, a more comprehensive comparison between river water and precipitation $\mathrm{H}$ and $\mathrm{O}$ isotopic ratios in basin-scale becomes necessary. In this regarding, our study provides the first practical synthesis of basin-scale precipitation $\delta^{18} \mathrm{O}$. As shown in Fig. $4 \mathrm{a}$, the basin-scale $\delta^{18} \mathrm{O}$ in the precipitation is nearly the same in each site but slightly vary due to variable climate and topography in the catchment. Our calculation indicates that the precipitation $\delta^{18} \mathrm{O}$ is high ( $-4 \%$ ) from January to May but decreases rapidly in June and remains in a lower value ( - 10\%o) until October. The $\delta^{18} 0$ then rises back to a higher value $(\sim-4 \%$ o) and maintains till the next year. Although our calculation may somewhat underestimate the complex precipitation processes in each sub-basin (Fig. 5 and Eq. (1)), dividing the basin into different sub-catchments based on its key tributaries does allow for a first-order estimation of $\delta^{18} \mathrm{O}$ in a basin-scale, made a significant difference compared to the previous attempts.

In comparison, the 2-year time series Changjiang river water $\delta^{18} \mathrm{O}$ in Nantong reveals similar seasonal variations with the precipitation, yielded high $\delta^{18} \mathrm{O}$ in winter and low $\delta^{18} \mathrm{O}$ in summer (Fig. 4a), suggests a potential correlation between river water and precipitation. The river water $\delta^{18} 0$ variation in Datong also displays a similar trend as that observed in Nantong, while the $\delta^{18} \mathrm{O}$ variation in Chongqing is different from those in Nantong and Datong. The river water $\delta^{18} \mathrm{O}$ in Chongqing is exceptionally high in May and June 2004. The reason behinds the phenomenon remains unclear but may be attributed to some specific climate or local events. Regardless of the several abnormal values observed in May and June, the river $\delta^{18} \mathrm{O}$ in Chongqing exhibits similar seasonal variations with those in Nantong and Datong, though the variation between winter and summer is not as notable as the latter two sites.

In contrast, the seasonal variations of $\delta^{18} \mathrm{O}$ in Poyang Lake are remarkably different from the other sites, showing a V-pattern with the lowest $\delta^{18} \mathrm{O}$ observed in June and July in the first monitoring year (Fig. 4a). This feature to some extent may be determined by evaporation depending on the local temperature and humidity. Apart from the trends, there are differences observed in absolute $\delta^{18} \mathrm{O}$ values between the precipitation and Changjiang river water. For instance, both the absolute values and the $\delta^{18} \mathrm{O}$ range in the Changjiang river water are smaller than that of the precipitation. This is probably due to the derivation of river water, primarily from precipitation upstream of the sampling location (i.e., at higher elevations), though the upstream $\delta^{18} \mathrm{O}$ values are often lower than local precipitation $\delta^{18} \mathrm{O}$, particularly in catchments with high elevation gradients [36]. Different isotopic ranges between river water and precipitation could be resulted from the catchment which receiving water tracer (e.g., $\delta^{18} 0$ ) inputs that were transported across diverse flow paths through the unsaturated and saturated zones as tracers migrate through the subsurface toward the stream network [48], thus the amplitudes of $\delta^{18} \mathrm{O}$ can be significantly dampened in river water relative to those of precipitation. Notably, the abrupt $\delta^{18} 0$ change in precipitation occurred between May and June, while the changes in the Changjiang river water took place between July and August (Fig. 4a). This inconsistency of $\delta^{18} \mathrm{O}$ variation may imply for a $~ 2$-month time lag of river water in response to precipitation. 
Despite the discussion above, the seasonal variations of $\delta^{18} O$ in the Changjiang river water are generally consistent with the basin-scale pattern of precipitation $\delta^{18} \mathrm{O}$. Combined the findings in this research, it is believed that the long-term $\delta^{18} 0$ time series in the Changjiang river water is mainly dominated by local precipitation. Nevertheless, it is worth mentioning that the isotopic signature of a river, especially for the enormous river, is multifaceted, can be altered by many hydrological processes, such as evaporation in the lakes and river surface [49], transpiration of vegetation [50, 51], and recharge from groundwater [52]. These hydrological processes, however, are beyond the scope of this study that focuses on the temporal variation of stable isotopes rather than the constraint of absolute isotopic value in the given catchment.

Our calculation on $\delta^{18} \mathrm{O}$ in precipitation over the Changjiang catchment may yield significant uncertainty due to limited isotopic observation stations available (mostly from GNIP) and antiquity of dataset (mainly in the late 1980s and 1990s). Nevertheless, this work provides the first attempt to estimate the seasonal variability of precipitation $\delta^{18} \mathrm{O}$ of the basin-scale and offers a quantitative isotopic comparison between river water and precipitation. As shown in Fig. 2a, the monthly precipitation average from Nanjing (GNIP station) in the lower Changjiang River is generally constant albeit the large seasonal fluctuations from 1987 to 1993, while a longer basin-scale precipitation record (Fig. 2b) in the Changjiang River also reveals a similar trend since the 1950s [16]. At the same time, the nationwide precipitation amount in China increases only by $2 \%$ from 1960 to 2000 [53], conforms with the findings in the Changjiang catchment. Similar to the precipitation pattern, the stable $\mathrm{H}$ and $\mathrm{O}$ isotopic compositions in precipitation (e.g., $\delta^{18} \mathrm{O}$ of precipitation in Nanjing, Fig. 2a) yielded significant seasonal variations but an overall constant annual average during the past several decades. Similar observations have also been recently reported [40] based on the dataset provided by the Chinese Network of Isotopes in Precipitation (CHNIP). In this case, our estimation of basin-scale $\delta^{18} \mathrm{O}$ in precipitation over the Changjiang catchment may serve as a long-term dataset, provides essential background for the future isotopic study in the Changjiang River.

\section{Water mixing determines the seasonal variation of $\delta^{18} 0$ in the lower Changjiang river water}

The stable isotopes seasonal pattern in the large river made a useful proxy to investigate the catchment hydrology, impacts of climate change and human activities on river discharges, and can be used to structure and validate on newly proposed hydrological models [27, 54]. However, the reasonable interpretation of seasonal stable isotopes variation depends mostly on the understanding of the hydrological setting and meteorological conditions of the river. For instance, the low-resolution isotopic sampling or hydrological monitoring may hinder the discovery of subtle relations between river water isotopes and local hydrological settings.

For the Changjiang river system, major tributaries are primarily located in the upper reaches of the Three Gorges except for the Hanjiang River, while many lakes, including the two largest lakes, Dongting Lake 
and Poyang Lake, are located in the middle and lower reaches. The Changjiang water discharge into the East China Sea is hence largely determined by the upstream contribution (regulated by Yichang gauging station) and the discharges from the Dongting and Poyang lakes (Fig. 4b). Here, we employ a simple conceptual model to quantitatively estimate the relative water contributions from the upper reaches and from the lakes to the lower Changjiang mainstream.

The water discharges data from Dongting Lake, Poyang Lake, and Hanjiang River were obtained from the gauging stations in Chenglingji, Hukou, and Huangzhuang, respectively. The river water discharge in Nantong is derived from the Datong gauging station as there is no regular gauging station in Nantong, and no significant tributaries exist between these two sites. Locations of each gauge station are shown in Fig. 1. Daily river water discharge data (November 2012 to December 2014) for all these stations is sourced from Changjiang Wuhan Waterway Bureau (http://yu-zhu.vicp.net/) and plotted in Fig. 4b. Apparently, the Hanjiang River only accounts for a small proportion (less than 1\%) of total discharge in Datong, which will not be considered in the following calculation.

The total water discharge from the Dongting Lake, Poyang Lakes, and Yichang upstream are very similar to that of Datong (Fig. 4b), suggesting that these three end-members predominantly supply the water discharge to the lower Changjiang mainstream in Datong. As Dongting and Poyang lakes have very similar temporal variations in water discharges (Fig. 4b) and isotopic compositions (Fig. 3), their total water discharges to the Changjiang mainstream are categorized under the same unit, as lake contribution. The river water across Nantong, therefore, can be simplified to merely two main endmembers, i.e., the source 1) from the Yichang upstream and 2) from the two lakes in the middle reaches (Fig. 6). In this case, the daily water contribution from the lakes to water discharge in Nantong can be simply calculated by Eq. (2):

$$
\text { Lake contribution }=\frac{D i s_{L}}{D i s_{L}+D i s_{Y C}}
$$

where $\mathrm{Dis}_{\mathrm{L}}$ and $\mathrm{Dis} \mathrm{Y}_{\mathrm{Y}}$ represent the water discharges from the lakes and the Yichang station, respectively. The calculated lake contribution to Changjiang discharge is presented in Fig. 4c. From the periods of November 2012 to June 2013 and March to July 2014, the Changjiang water discharge in Nantong is primarily sourced from the lakes. In other months during the monitoring period, the upper catchment upstream of Yichang has supplied much water to the lower Changjiang mainstream.

The injection of the lake water with higher $\delta^{18} 0$ due to evaporation [30], to the Changjiang mainstream, causes elevated $\delta^{18} O$ in the Changjiang river water downstream of the lakes (Figs. 3 and 4a) [20, 23, 31]. From the periods of July 2013 to late February 2014, and from July to December 2014, the river water $\delta^{18} \mathrm{O}$ values in Nantong are relatively low, which corresponds to the reducing water contribution from the lakes. It is interesting to note that the $\delta^{18} \mathrm{O}$ in the lower Changjiang river water does not vary 
synchronously with the lakes' water contribution but with a time lag (Fig. 4b). A non-linear correlation analysis between the $\delta^{18} 0$ time series and daily lake contribution indicates that a forward shift of the $\delta^{18} O$ curve by about 17 days yields the best correlation $\left(R^{2}=0.69\right)$ between these two curves (Fig. $\left.4 \mathrm{c}\right)$. This finding suggests that the seasonal variations of river water $\delta^{18} \mathrm{O}$ in Nantong are closely related to the water mixing from the Changjiang upstream and the lakes (Dongting and Poyang Lakes). In addition, the 17-days' time-lag between river water isotopic signals and lake water contribution indicates that it takes about two weeks for the river water to travel from the middle reaches to the river mouth.

Consequently, the $\delta^{18} \mathrm{O}$ signal in Nantong was two weeks lagged after the river water mixing in the middle reaches.

In conclusion, the time-series investigation of river water isotopic signatures and water discharges at the four key hydrometric stations in the Changjiang River demonstrates that the river water $\delta^{18} \mathrm{O}$ variation in Nantong is in general defined by local precipitation but more directly related to the river water mixing in middle-lower reaches. The water contributions from the upstream and tributary lakes thus determine the daily $\delta^{18} \mathrm{O}$ variation in the Changjiang river downstream.

\section{Damming impacts on the water cycle and river water isotopes in the lower Changjiang mainstream}

Nowadays, the water discharge in the Changjiang mainstream at Yichang station is controlled mainly by the anthropogenic regulation (impounding/releasing) of the Three Gorges Reservoir (TGR) since its first impoundment in 2003. The impact of TGR on the Changjiang water discharge is not confined to only annual scale [18, 55-58] but also seasonal scale [59-61]. The regulation of TGR impoundment determines the water discharge downstream in Yichang and consequently controlled the water mixing between the Changjiang mainstream and the lakes [31]. From August to December 2013, the TGR was impounded (indicated by the high water level in TGR) to lower the flood risk to the downstream region, which subsequently results in a higher contribution of the lake water to the lower mainstream. On the contrary, the TGR released the water from December 2013 to May 2014 for shipping and irrigation, which consequences in a higher upstream contribution relative to the lake contribution.

To better expose the damming effect on the water mixing and stable isotopes in the lower Changjiang river water, we examined the relationship between the water samples $\delta^{18} \mathrm{O}$ and the frequency (\%) of its occurrence in the mid-lower Changjiang (Fig. 6). The data indicates that $\delta^{18} O$ variability $\left(\delta^{18} 0\right.$ range in $X$ axis) in the upper mainstream (Chongqing) above the TGR is more substantial than that in the mid-lower Changjiang mainstream (Nantong and Datong) and Poyang Lake. The Nantong and Datong sites are located downstream of TGR. The river water sourced from the upper Changjiang basin retained in the vast reservoir is well-mixed during the TGR impoundment may result in a homogenized isotopic signal. Furthermore, there are two prominent $\delta^{18} \mathrm{O}$ peaks observed in the river water in Nantong and Chongqing in Fig. 6, corresponds to the two notable $\delta^{18} 0$ values measured during the summer and winter (Fig. 4a). 
However, these temporal features are less pronounced in the water samples from Datong and Poyang Lake; values generated were probably insignificant statistically due to fewer water samples available.

It is noteworthy that apart from the damming effect, other environmental factors such as evapotranspiration and the mixing of groundwater can also impact the $\delta^{18} O$ in river water $[50,51]$. These influences are, however, hard to be quantified thus clarify in this paper due to limited stable $\mathrm{H}$ and $\mathrm{O}$ isotopic data retrieved from the soil, vegetation, and underground water in the catchment. Further modeling work may help in making a quantitative assessment of the evapotranspiration contribution to the river water $\delta^{18} 0$ possible in the future.

\section{Conclusions}

In this contribution, we report a two-year time series of $\delta^{18} \mathrm{O}$ in the Changjiang river water and discuss the natural and anthropogenic forcing on the $\delta^{18} \mathrm{O}$ variation. The sub-basin weighed $\delta^{18} \mathrm{O}$ in precipitation over the Changjiang catchment is calculated by the long-term meteorological observation data and multiyear $\delta^{18} \mathrm{O}$ record from GNIP. The monsoon-induced precipitation in overall determines the temporal variations of $\delta 180$ in the lower Changjiang mainstream in Nantong, but more straightforwardly related to the mixing of different waters from the upper Changjiang mainstream above Yichang and the tributary lakes in the middle reach. A comparison of river water $\delta^{18} 0$ with discharge contribution from the lakes suggests that it takes about two weeks ( 17 days) for the Changjiang river water to travel through the mid-lower reaches to the sea. The TGR has changed the temporal variability of river $\delta^{18} 0$, through regulating the water releasing in the mid-lower reaches.

This research suggests that the temporal variations of water stable isotopes in larger rivers are driven by composite factors. Apart from the natural climatic constraints, the local hydrological conditions must be taken into account in such a study. Besides, the estimation of basin-scale $\delta^{18} O$ in precipitation may be an essential complement for water cycle modeling in the Changjiang catchment, and also provides baseline data for other hydrological isotope studies.

\section{Supplementary Information}

Supplementary information accompanies this paper

\section{Abbreviations}

IAEA: International Atomic Energy Agency; GNIR: Global Network of Isotopes in Rivers (GNIR); TGR: Three Gorges Reservoir; (GNIP) global network of isotopes in precipitation; LMWL: local meteoric water line.

Chinese Network of Isotopes in Precipitation (CHNIP)

\section{Declarations}


Ethics approval and consent to participate

Not applicable

Consent for publication

Not applicable

\section{Availability of data and material}

All data generated or analyzed during this study are included in this published article [and its supplementary information files].

\section{Competing interests}

The authors declare that they have no competing interests

\section{Funding}

This work was supported by the National Natural Science Foundation of China (Grant No: 41676035 and 41730531) and National Programme on Global Change and Air-Sea Interaction (GASI-GEOGE-03).

\section{Authors' contributions}

$C L, E L, C Y$ and SY were involved in the experiments and manuscript writing. $C L, K D$, and $P Q$ were responsible for the sample acquisition. $\mathrm{CL}$ and $\mathrm{SY}$ designed the study. SX and ZL contributed to comments on this manuscript. All authors read and approved the final manuscript.

\section{Acknowledgments}

We thank Shilun Yang and Zhijun Dai (both from East China Normal University) for providing the river discharge data of the Changjiang River. $\mathrm{CL}$ is grateful to Nicholas $\mathrm{Ng}$ Chia Wei for his help in improving the English language.

\section{References}

1. Kendall C, Coplen TB (2001) Distribution of oxygen-18 and deuterium in river waters across the United States. Hydrol Process 15: 1363-1393

2. Gibson JJ, Aggarwal P, Hogan J, Kendall C, Martinelli LA, Stichler W, Rank D, Goni I, Choudhry M, Gat $J$ (2002) Isotope studies in large river basins: a new global research focus. EOS, Transactions American Geophysical Union 83: 613-617

3. Gat JR (1996) Oxygen and hydrogen isotopes in the hydrologic cycle. Annu Rev Earth PI Sc 24: 225262 
4. Gibson JJ, Fekete BM, Bowen GJ (2010) Stable Isotopes in Large Scale Hydrological Applications. In: West JB, Bowen GJ, Dawson TE, Tu KP (ed) Isoscapes: Understanding Movement, Pattern, and Process on Earth Through Isotope Mapping. Springer, New York, p 389-405

5. Good SP, Noone D, Kurita N, Benetti M, Bowen GJ (2015) D/H isotope ratios in the global hydrologic cycle. Geophys Res Lett 42: 5042-5050

6. Soulsby C, Birkel C, Geris J, Tetzlaff D (2015) The isotope hydrology of a large river system regulated for hydropower. River Res Appl 31: 335-349

7. Vitvar T, Aggarwal PK, McDonnell JJ (2005) A Review of Isotope Applications in Catchment Hydrology. In: Aggarwal P, Gat J, Froehlich KO (ed) Isotopes in the Water Cycle. Springer Netherlands, p 151-169

8. Gibson JJ, Edwards T, Birks SJ, St Amour NA, Buhay WM, McEachern P, Wolfe BB, Peters DL (2005) Progress in isotope tracer hydrology in Canada. Hydrol Process 19: 303-327

9. Darling WG, Bath AH, Gibson JJ, Rozanski K (2006) Isotopes in water. In: Leng MJ (ed) Isotopes in Palaeoenvironmental Research. Springer, Dordrecht, p 1-66

10. Aggarwal PK, Araguás-Araguás LJ, Groening M, Kulkarni KM, Kurttas T, Newman BD, Vitvar T (2010) Global hydrological isotope data and data networks. In: West JB, Bowen GJ, Dawson TE, Tu KP (ed) Isoscapes: Understanding Movement, Pattern, and Process on Earth Through Isotope Mapping. Springer, New York, p 33-50

11. Zong Y, Chen X (2000) The 1998 flood on the Yangtze, China. Nat Hazards 22: 165-184

12. Müller B, Berg M, Yao ZP, Zhang XF, Wang D, Pfluger A (2008) How polluted is the Yangtze river? Water quality downstream from the Three Gorges Dam. Sci Tot Environ 402: 232-247

13. Wu J, Huang J, Han X, Gao X, He F, Jiang M, Jiang Z, Primack RB, Shen Z (2004) The three gorges dam: an ecological perspective. Front Ecol Environ 2: 241-248

14. Long H, Heilig G, Wang J, Li X, Luo M, Wu X, Zhang M (2006) Land use and soil erosion in the upper reaches of the Yangtze River: some socio-economic considerations on China's Grain-for-Green Programme. Land Degrad Dev 17: 589-603

15. Wang J, Sheng Y, Gleason CJ, Wada Y (2013) Downstream Yangtze River levels impacted by Three Gorges Dam. Environ Res Lett 8: 044012

16. Yang SL, Xu KH, Milliman JD, Yang HF, Wu CS (2015) Decline of Yangtze River water and sediment discharge: Impact from natural and anthropogenic changes. Sci Rep 5: 12581

17. Yang S, Milliman J, Li P, Xu K (2011) 50,000 dams later: Erosion of the Yangtze River and its delta. Global Planet Change 75: 14-20

18. Yang CF, Yang SY, Song JZ, Vigier N Progressive Evolution of the Changjiang (Yangtze River) Sediment Weathering Intensity Since the Three Gorges Dam Operation. Journal of Geophysical Research-Earth Surface

19. Lai X, Yin D, Finlayson BL, Wei T, Li M, Yuan W, Yang S, Dai Z, Gao S, Chen Z (2017) Will river erosion below the Three Gorges Dam stop in the middle Yangtze? J Hydrol 554: 24-31 
20. Lu B, Sun T, Wang C, Dai S, Kuang J, Wang J (2012) Temporal and spatial variations of $\delta^{18} \mathrm{O}$ along the main stem of the Yangtze River, China, In: IAEA, Monitoring Isotopes in Rivers: Creation of the Global Network of Isotopes in Rivers (GNIR), Results of a Coordinated Research Project 2002-2006, Vienna, p 211-219

21. Li S, Liu C, Li J, Liu X, Chetelat B, Wang B, Wang F (2010) Assessment of the sources of nitrate in the Changjiang River, China using a nitrogen and oxygen isotopic approach. Environ Sci Technol 44: 1573-1578

22. Liu Y, An S, Xu Z, Fan N, Cui J, Wang Z, Liu S, Pan J, Lin G (2008) Spatio-temporal variation of stable isotopes of river waters, water source identification and water security in the Heishui Valley (China) during the dry-season. Hydrogeol J 16: 311-319

23. Ding TP, Gao JF, Tian SH, Shi GY, Chen F, Wang CY, Luo XR, Han D (2014) Chemical and Isotopic Characteristics of the Water and Suspended Particulate Materials in the Yangtze River and Their Geological and Environmental Implications. Acta Geogr Sin 88: 276-360

24. Li S-L, Liu C-Q, Patra S, Wang F, Wang B, Yue F (2011) Using a dual isotopic approach to trace sources and mixing of sulphate in Changjiang Estuary, China. Appl Geochem 26: S210-S213

25. Deng K, Yang S, Lian E, Li C, Yang C, Wei H (2016) Three Gorges Dam alters the Changjiang (Yangtze) river water cycle in the dry seasons: Evidence from H-O isotopes. Sci Tot Environ 562: 8997

26. Li C, Yang S, Lian E, Yang C, Deng K, Liu Z (2016) Damming effect on the Changjiang (Yangtze River) river water cycle based on stable hydrogen and oxygen isotopic records. J Geochem Explor 165: 125133

27. Jiang R, Bao Y, Shui Y, Wang Y, Hu M, Cheng Y, Cai A, Du P, Ye Z (2018) Spatio-Temporal Variations of the Stable $\mathrm{H}-\mathrm{O}$ Isotopes and Characterization of Mixing Processes between the Mainstream and Tributary of the Three Gorges Reservoir. Water 10: 563

28. Wu H, Li J, Song F, Zhang Y, Zhang H, Zhang C, He B (2018) Spatial and temporal patterns of stable water isotopes along the Yangtze River during two drought years. Hydrol Process 32: 4-16

29. Rozanski K, Araguás-Araguás L, Gonfiantini R (1993) Isotopic patterns in modern global precipitation. In: Swart PK, Lohmann KC, McKenzie JA, Savin SM (ed) Climate change in continental isotopic records. Wiley Online Library, p 1-36

30. Hu C, Froehlich K, Zhou P, Lou Q, Zeng S, Zhou W (2013) Seasonal variation of oxygen-18 in precipitation and surface water of the Poyang Lake Basin, China. Isot Environ Health Stud 49: 188196

31. Zhan L, Chen J, Zhang S, Li L, Huang D, Wang T (2016) Isotopic signatures of precipitation, surface water, and groundwater interactions, Poyang Lake Basin, China. Environ Earth Sci 75: 1307

32. Müller B, Berg M, Pernet-Coudrier B, Qi W, Liu H (2012) The geochemistry of the Yangtze River: Seasonality of concentrations and temporal trends of chemical loads. Global Biogeochem Cy 26: GB2028 
33. Araguás-Araguás L, Froehlich K, Rozanski K (1998) Stable isotope composition of precipitation over southeast Asia. J Geophys Res 103: 28721-28742

34. Ding Y, Chan JC (2005) The East Asian summer monsoon: an overview. Meteorol Atmos Phys 89: 117-142

35. Qian W, Kang HS, Lee DK (2002) Distribution of seasonal rainfall in the East Asian monsoon region. Theor Appl Climatol 73: 151-168

36. Dutton A, Wilkinson BH, Welker JM, Bowen GJ, Lohmann KC (2005) Spatial distribution and seasonal variation in ${ }^{18} \mathrm{O} /{ }^{16} \mathrm{O}$ of modern precipitation and river water across the conterminous USA. Hydrol Process 19: 4121-4146

37. Craig H (1961) Isotopic variations in meteoric waters. Science 133: 1702-1703

38. Zhang $X$, Yao $T$ (1998) Distributional features of $\delta^{18} O$ inprecipitation in China. The Journal of Chinese Geography 8: 157-164

39. Dansgaard W (1964) Stable isotopes in precipitation. Tellus 16: 436-468

40. Liu J, Song X, Yuan G, Sun X (2014) Stable isotopic compositions of precipitation in China. Tellus B 66: 22567

41. Johnson KR, Ingram BL (2004) Spatial and temporal variability in the stable isotope systematics of modern precipitation in China: implications for paleoclimate reconstructions. Earth Planet Sci Lett 220: $365-377$

42. Liu J, Song X, Yuan G, Sun X, Liu X, Wang S (2009) Characteristics of $\delta^{18} O$ in precipitation over Eastern Monsoon China and the water vapor sources. Chin Sci Bull 55: 200-211

43. Lee JE, Risi C, Fung I, Worden J, Scheepmaker RA, Lintner B, Frankenberg C (2012) Asian monsoon hydrometeorology from TES and SCIAMACHY water vapor isotope measurements and LMDZ simulations: Implications for speleothem climate record interpretation. J Geophys Res 117: D15112

44. Posmentier ES, Feng X, Zhao M (2004) Seasonal variations of precipitation $\delta 180$ in eastern Asia. J Geophys Res 109: D23106

45. Li Y, Zhang M, Wang S, Li Z, Wang F (2012) Stable isotope in precipitation in China: A review. Sciences in Cold and Arid Regions 4: 83-90

46. Liu Z, Tian L, Chai X, Yao T (2008) A model-based determination of spatial variation of precipitation $\delta^{18} \mathrm{O}$ over China. Chem Geol 249: 203-212

47. Tan M (2014) Circulation effect: response of precipitation $\delta^{18} O$ to the ENSO cycle in monsoon regions of China. Clim Dyn 42: 1067-1077

48. McGuire KJ, McDonnell JJ (2006) A review and evaluation of catchment transit time modeling. J Hydrol 330: 543-563

49. Cockerton H, Street-Perrott F, Leng M, Barker P, Horstwood M, Pashley V (2013) Stable-isotope (H, O, and $\mathrm{Si}$ ) evidence for seasonal variations in hydrology and Si cycling from modern waters in the Nile Basin: implications for interpreting the Quaternary record. Quat Sci Rev 66: 4-21 
50. Jasechko S, Sharp ZD, Gibson JJ, Birks SJ, Yi Y, Fawcett PJ (2013) Terrestrial water fluxes dominated by transpiration. Nature 496: 347-350

51. Good SP, Noone D, Bowen G (2015) Hydrologic connectivity constrains partitioning of global terrestrial water fluxes. Science 349: 175-177

52. Kanduč T, Grassa F, McIntosh J, Stibilj V, Ulrich-Supovec M, Supovec I, Jamnikar S (2014) A geochemical and stable isotope investigation of groundwater/surface-water interactions in the Velenje Basin, Slovenia. Hydrogeol J 22: 971-984

53. Liu B, Xu M, Henderson M, Qi Y (2005) Observed trends of precipitation amount, frequency, and intensity in China, 1960-2000. J Geophys Res 110: D08103

54. Ogrinc N, Kanduč T, Stichler W, Vreča $P(2008)$ Spatial and seasonal variations in $\delta^{18} O$ and $\delta D$ values in the River Sava in Slovenia. J Hydrol 359: 303-312

55. Dai Z, Du J, Li J, Li W, Chen J (2008) Runoff characteristics of the Changjiang River during 2006: Effect of extreme drought and the impounding of the Three Gorges Dam. Geophys Res Lett 35: L07406

56. Yang Z, Wang H, Saito Y, Milliman JD, Xu K, Qiao S, Shi G (2006) Dam impacts on the Changjiang (Yangtze) River sediment discharge to the sea: The past 55 years and after the Three Gorges Dam. Water Resour Res 42: W04407

57. Chen X, Zong Y, Zhang E, Xu J, Li S (2001) Human impacts on the Changjiang (Yangtze) River basin, China, with special reference to the impacts on the dry season water discharges into the sea. Geomorphology 41: 111-123

58. Yang S, Liu Z, Dai S, Gao Z, Zhang J, Wang H, Luo X, Wu C, Zhang Z (2010) Temporal variations in water resources in the Yangtze River (Changjiang) over the Industrial Period based on reconstruction of missing monthly discharges. Water Resour Res 46: W10516

59. Guo H, Hu Q, Zhang Q, Feng S (2012) Effects of the Three Gorges Dam on Yangtze River flow and river interaction with Poyang Lake, China: 2003-2008. J Hydrol 416-417: 19-27

60. Xu K, Milliman JD (2009) Seasonal variations of sediment discharge from the Yangtze River before and after impoundment of the Three Gorges Dam. Geomorphology 104: 276-283

61. Gao B, Yang D, Yang H (2013) Impact of the Three Gorges Dam on flow regime in the middle and lower Yangtze River. Quat Int 304: 43-50

\section{Figures}


Fig. 1

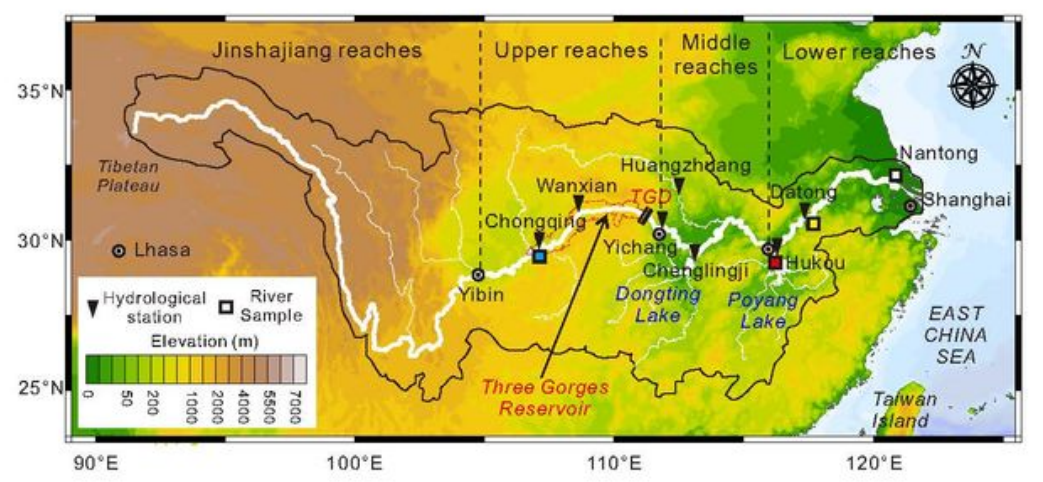

\section{Figure 1}

Map of the Changjiang River catchment with the sampling sites. Major lakes and tributaries and the Three Gorges Dam (TGD) are indicated. Note: The designations employed and the presentation of the material on this map do not imply the expression of any opinion whatsoever on the part of Research Square concerning the legal status of any country, territory, city or area or of its authorities, or concerning the delimitation of its frontiers or boundaries. This map has been provided by the authors. 
Fig. 2
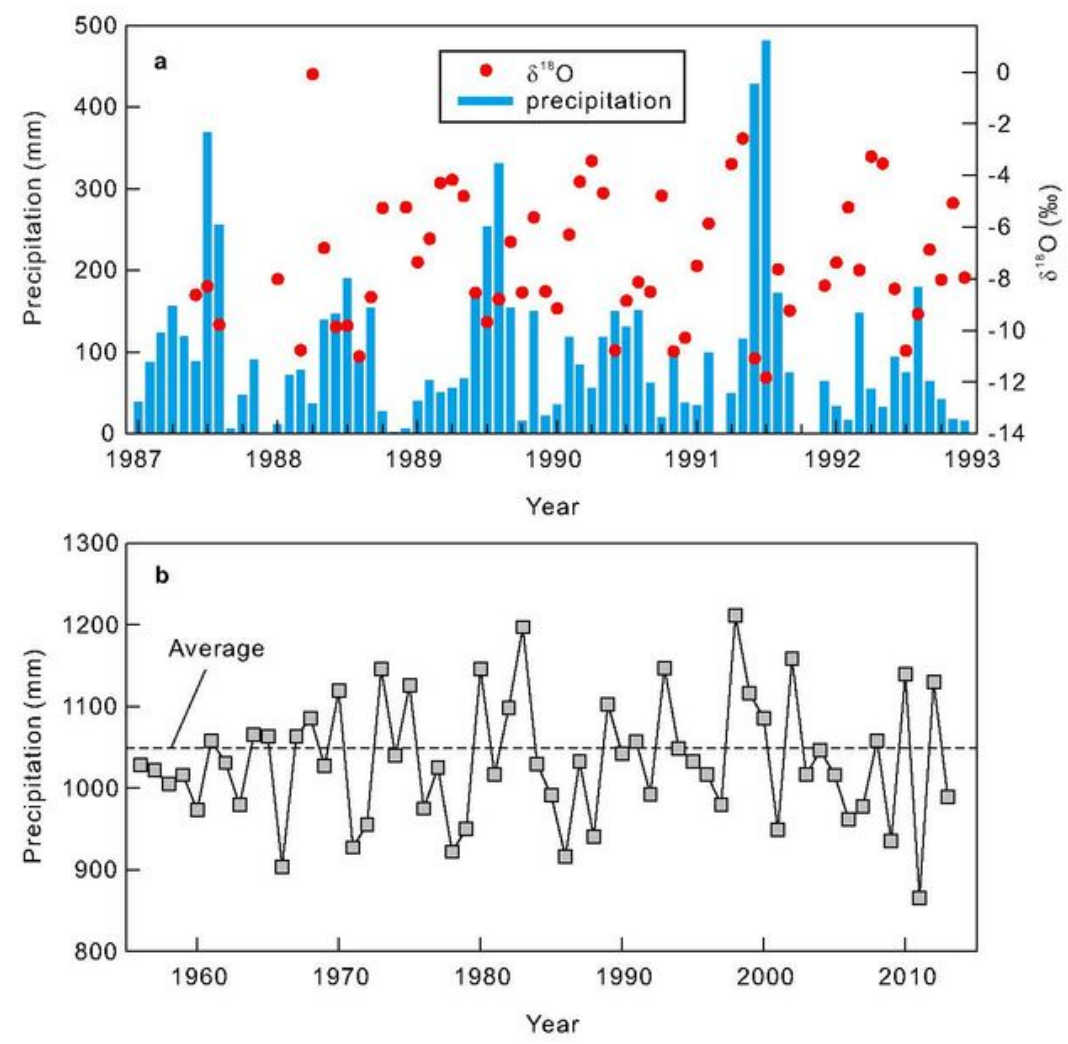

\section{Figure 2}

Multi-year (1987-1993) precipitation in Nanjing (a) and the Changjiang catchment (b). Precipitation $\delta 180$ in Nanjing is likewise indicated in (a). Precipitation amount and $\delta 180$ in Nanjing are retrieved from GNIP, while the precipitation data of the Changjiang catchment is referred from Yang et al. [16]. 
Fig. 3

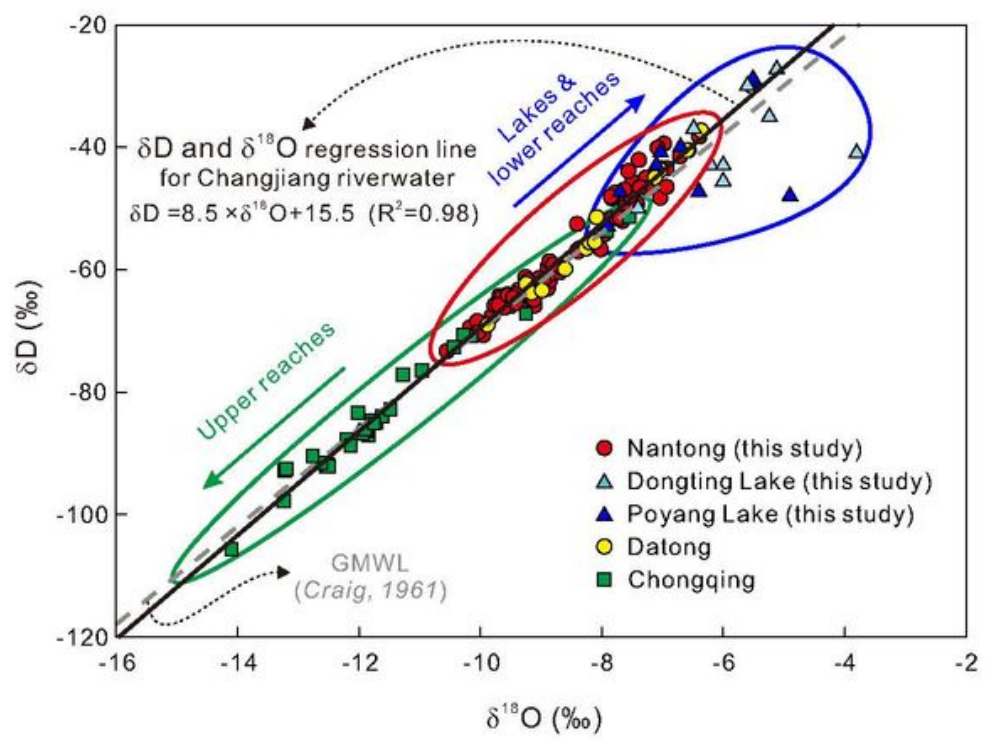

\section{Figure 3}

The plot of $\delta D$ v.s. $\delta 180$ for the Changjiang river and lake water samples. Reference water samples from the Changjiang River in Chongqing and Datong, Dongting Lake and Poyang Lake are also included for the comparison (See details in the Supplementary Table 1). Global Meteoric Water Line (GMWL) is derived from Craig [37]. $\delta D$ and $\delta 180$ regression line for the Changjiang river water is calculated based on the samples obtained from Nantong, Datong, and Chongqing sites. 
Fig. 4
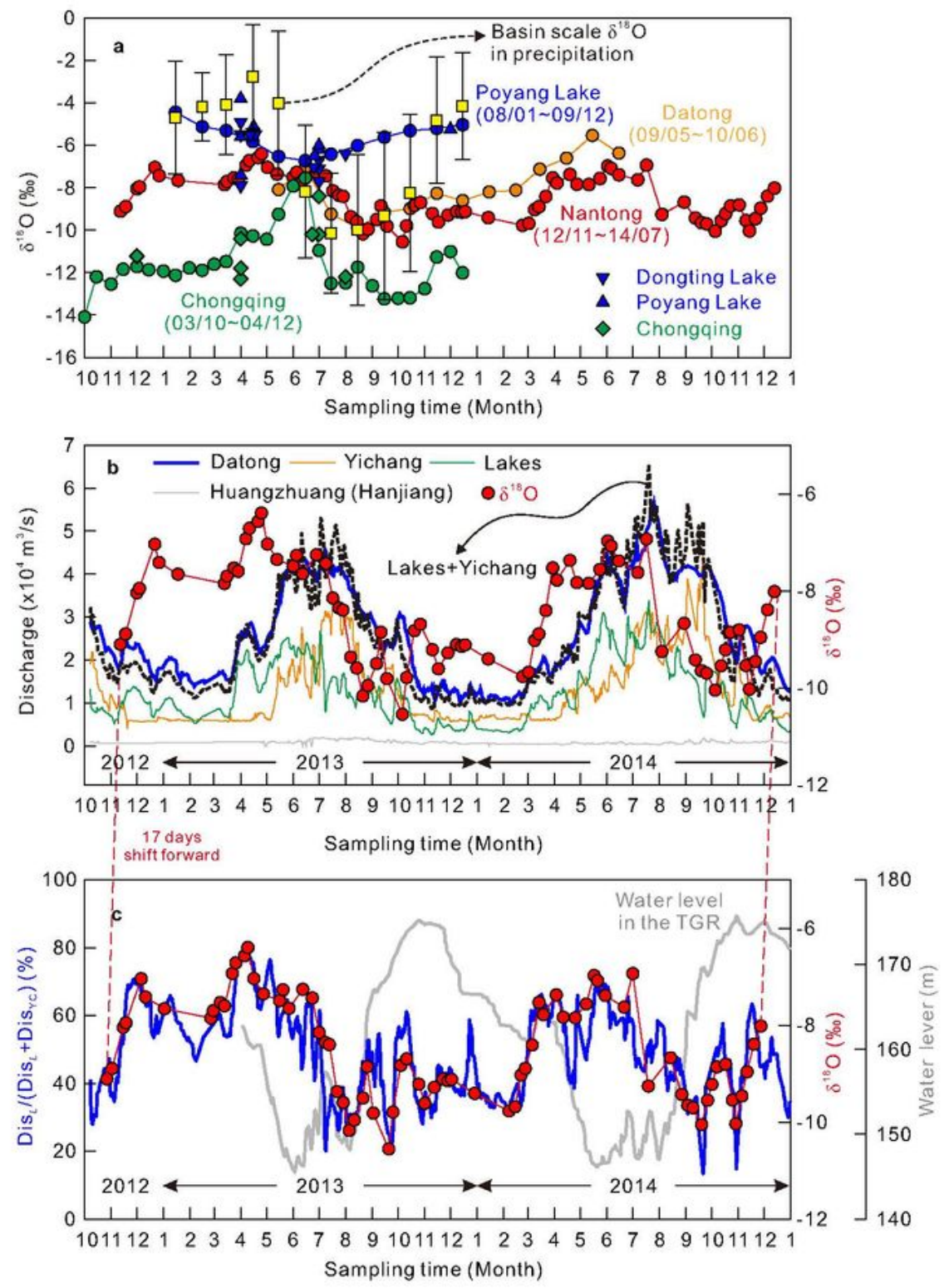

\section{Figure 4}

(a) Time series of $\delta 180$ in the Changjiang river water in Nantong and precipitation over the Changjiang catchment. The $2 \sigma$ errors for precipitation are calculated with equation (1) based on the deviation for monthly precipitation for each sub-basin (see Table 1). See the text for a detailed calculation of precipitation isotopic composition. Time series of $\delta 180$ in Changjiang River in Chongqing and Datong, Dongting Lake and Poyang Lake are likewise compared. The sampling time for each time series is shown 
in bracket (YY/MM YY/MM) (b) Daily river discharge data of the Changjiang River at different gauge stations from October 2012 to December 2014. All discharge data refers to http://yu-zhu.vicp.net/. The temporal variations of $\delta 180$ in the Changjiang river water in Nantong are displayed for the comparison. (c) Correlation between $\delta 180$ time series (17 days shift forward) in the Changjiang river water in Nantong and the defined lake contribution in terms of water discharge ratio. The water level at the Three Gorges Reservoir is retrieved from the Wanxian Station (http://yu-zhu.vicp.net/).

Fig. 5

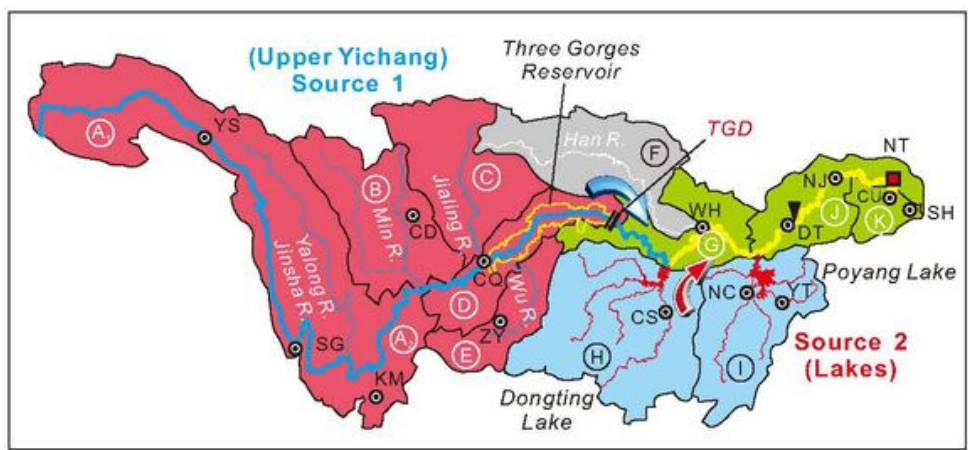


A two-end-member model shows the water mixing in the Changjiang mainstream. Source 1 indicates the contribution from catchment upstream, Yichang and Source 2 indicates the contribution of Dongting and Poyang Lakes in the middle valley. The sub-basins were defined based on different tributary systems and are labeled with a capital letter from A1 to K. Note that the Jinshajiang sub-basin is further divided into two parts (the region upstream Shigu (A1) and downstream Shigu (A2), due to two distinct topography and climate regimes span across the Jinshajiang catchment. The stations for isotopic sampling and meteorological data are likewise indicated in this figure. Refer to Tables 1 and 2 for details of the abbreviations for each station. Note: The designations employed and the presentation of the material on this map do not imply the expression of any opinion whatsoever on the part of Research Square concerning the legal status of any country, territory, city or area or of its authorities, or concerning the delimitation of its frontiers or boundaries. This map has been provided by the authors. 
Fig. 6

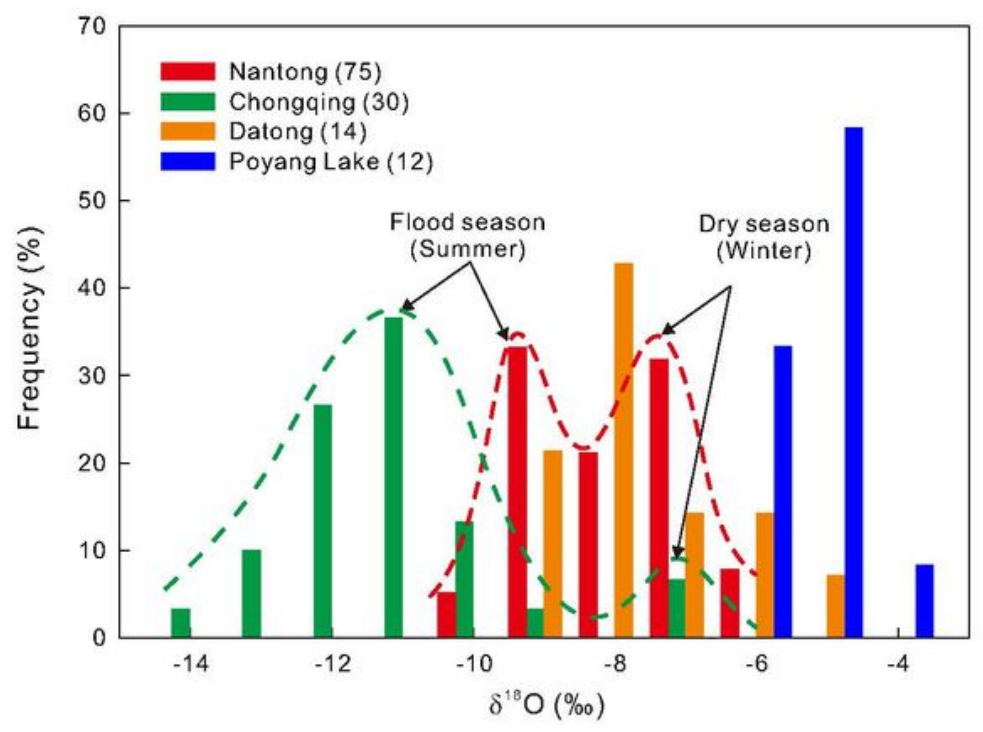

Figure 6

$\delta 180$ in the water samples and frequency (\%) of its occurrence in the Changjiang River and Poyang Lake. Sample numbers are indicated in the bracket.

\section{Supplementary Files}


This is a list of supplementary files associated with this preprint. Click to download.

- Supplementarydata.xIsx

Table 2

Basin area and precipitation amount for each Changjiang sub-basin

$\begin{array}{llllllllll}Y^{\mathrm{a}} & \mathrm{KM} & \mathrm{CD} & \mathrm{CQ} & \mathrm{ZY} & \mathrm{CS} & \text { WH } & \text { NC } & \text { NJ } & \text { SH } \\ \left(\mathrm{A}_{1}\right)^{\mathrm{b}} & \left(\mathrm{A}_{2}\right) & (B) & (\mathrm{C}, \mathrm{D}) & (\mathrm{E}) & (\mathrm{H}) & (\mathrm{G}, \mathrm{F}) & (\mathrm{I}) & (\mathrm{J}) & (\mathrm{K})\end{array}$

Area for each sub-basin $\left(\times 10^{4} \mathrm{~km}^{2}\right)$

$\begin{array}{llllllllll}21.42 & 28.05 & 16.34 & 26.52 & 7.59 & 25.24 & 25.47 & 15.64 & 10.53 & 3.21\end{array}$

Precipitation $(\mathrm{mm})$ for selective meteorological stations in each sub-basin

\begin{tabular}{|lllllllllll|}
\hline Jan & 4.0 & 13.5 & 9.1 & 19.3 & 23.4 & 75.6 & 40.4 & 67.0 & 36.8 & 66.2 \\
\hline Feb & 4.5 & 12.3 & 8.3 & 21.1 & 21.9 & 91.5 & 62.6 & 99.9 & 52.7 & 63.2 \\
\hline Mar & 8.6 & 16.5 & 25.0 & 42.6 & 38.4 & 142.4 & 97.2 & 172.1 & 75.0 & 89.7 \\
\hline Apr & 14.5 & 22.8 & 35.5 & 92.9 & 85.5 & 182.9 & 137.5 & 216.7 & 82.9 & 68.5 \\
\hline May & 54.6 & 89.8 & 104.9 & 152.2 & 147.0 & 200.1 & 169.0 & 256.0 & 92.4 & 82.6 \\
\hline Jun & 99.5 & 175.4 & 111.7 & 180.0 & 195.9 & 224.8 & 216.4 & 292.0 & 164.2 & 175.7 \\
\hline Jul & 102.0 & 204.6 & 224.6 & 160.0 & 149.9 & 151.7 & 191.6 & 128.6 & 197.2 & 134.6 \\
\hline Aug & 87.2 & 196.0 & 170.3 & 133.5 & 126.4 & 108.5 & 120.1 & 112.5 & 129.8 & 202.2 \\
\hline Sep & 74.7 & 117.2 & 119.3 & 123.4 & 93.3 & 82.1 & 83.3 & 70.9 & 81.4 & 79.5 \\
\hline Oct & 28.8 & 83.4 & 47.0 & 92.1 & 102.1 & 66.5 & 71.1 & 54.4 & 51.1 & 61.3 \\
\hline Nov & 2.9 & 35.9 & 15.3 & 48.1 & 48.1 & 76.2 & 53.2 & 65.4 & 49.9 & 51.0 \\
\hline Dec & 1.7 & 13.1 & 6.2 & 24.3 & 24.0 & 49.1 & 28.8 & 46.5 & 28.9 & 43.4 \\
\hline a & & & & & & & & & & \\
\hline
\end{tabular}

${ }^{a}$ Data on the precipitation amount for each meteorological station in the Changjiang catchment is retrieved from the Chinese Meteorological Data Share Service System

(http://cdc.cma.gov.cn/home.do). Abbreviations: $Y S=$ Yushu, $K M=$ Kunming, $C D=$ Chengdu, $C Q=$ Chongqing, $\mathrm{ZY}=$ Zunyi, $\mathrm{CS}=$ Changsha, $\mathrm{WH}=$ Wuhan, $\mathrm{NC}=$ Nanchang, $\mathrm{NJ}=\mathrm{Nanjing}$, and $\mathrm{SH}=$ Shanghai.

b The 12 sub-basins of the Changjiang catchment are indicated by capital letters from $A_{1}$ to $K$ (See Fig. 5). 